areas had a fairly high infection-rate with $W$. bancrofti.

One possible explanation of these findings has been tested, namely, the suggestion that the parallel development of filaria larvæ and malaria parasites cannot normally proceed to maturity in the same mosquito. An unusual opportunity for testing this was provided by a five-year old African child who was a chronic infector with both falciparum malaria and $W$. bancrofti. On two occasions batches of laboratory-bred Anopheles gambice were fed on him at night between 9 and 10 p.m. Out of 49 gambice surviving for dissection from ten days onward, 15 were found infected with malaria or filaria; of that number 2 showed mixed infections of mature thoracic larvæ and mature oocysts, and one was infected with both sporozoites and mature filaria larvæ in thorax and head.

Although these mixed advanced infections appear to be so scarce in Nature, these experiments show that both infections can actually proceed side by side and that there is no physiological barrier to prevent one and the same anopheline picking up both infections from the human host, and in turn becoming infective with both parasites.

In trying to interpret these figures it must be remembered that when the malarial infection has reached the sporozoite stage in the salivary glands of the mosquito, the infection may persist there for many days or even weeks. With the filarial infection, however, the infective stages in the head and proboscis are fairly transitory, and within about fifteen days of the infective feed they may have left the mosquito without leaving any trace behind. When we find a mosquito with a sporozoite infection we know that it must be at least ten days old; but it may, of course, be a much older mosquito which has also acquired, developed and finally lost a filarial infection.

These observations form part of a much wider investigation into the relative importance of each human age group in the African village community as a source of malarial and filarial infection. It is hoped that the outcome of this work may provide a satisfactory explanation of this curious mutual exclusion of advanced malarial and filarial infections in Anopheles gambice. Colonial Medical Research,

London School of Hygiene and Tropical Medicine, Keppel Street,
London, W.C.1. April 5.

'Raghavan, N. G. S., Misra, B. G., and Roy. R., N w tuture, 170, 253 (1952).

\section{Pseudotuberculosis among Stock-Doves in Hampshire}

During December 1952, many stock-doves were found lying dead under the trees where they normally roost in the Damerham-Martin district of Hampshire. They appeared to be in good condition, but postmortem examination of forty-two of them showed that death was due to a virulent strain of Pasteurella pseudotuberculosis. There were small caseating nodules in the liver and spleen, both of which organs were slightly enlarged. The outbreak continued throughout December and January, but began to decrease in February.
In order to find what other species were carrying the infection, all birds and rodents found dead in the district were examined, and many others were shot for examination. These included seventeen wood pigeons, one lark, one redwing, twenty-seven jackdaws, seven rooks, three jays, one sparrow, nine rabbits, six hares and fifty-two grey squirrels, and the bacterium was recovered from the lark, one wood pigeon, one jackdaw, one rook and one hare. The lark had been picked up dead, and the liver showed a close network of caseating fibres which traversed the whole organ, while the spleen contained two outstanding nodules about the size of a pin-head. Bacteria were recovered from both organs. The other infections were found in shot animals and were cryptic, for no signs of disease were noted in any organ. An attempt to infect bantam chicks gave negative results.

Many bodies are sent to this laboratory for examination, and during this period the bacterium was recovered from a rabbit in Hertfordshire and from two pigeons from Norfolk.

This infection has been repeatedly reported from rodents and sporadically from birds, though more serious outbreaks have been described from turkeys', fowls and pheasants ${ }^{2}$ and from ducklings ${ }^{3}$. We ourselves have isolated the bacterium from grey partridge, pheasant and bob white quail, the latter being a bird reared in captivity. On this occasion, however, there seemed to be little disease among rodents, and it is particularly interesting that the wood pigeons were not seriously affected, in spite of their close affinity to stock-doves. Though the number of wild birds examined was small, there is evidence that several distinct species may be reservoirs of infection.

I.C.I. Game Services, P. A. Clapham

Game Research Station,

Burgate Manor,

Fordingbridge,

Hampshire.

March 26.

1 Beck, A., and Huck, W., Centralbl. f. Bakt., 1, 95, 330 (1925).

3 Truche, C., and Bauche, J., Bul. Acad. Vet. Fr., 6, 43 (1933).

'Truche, C., and Bauche, J., Bul. Acad. Vet. Fr., 3, 391 (1930).

\section{Storage of Unfertilized Rabbit Ova : Subsequent Fertilization and the Probability of Normal Development}

Previous investigations ${ }^{1-3}$ have shown that fertilized rabbit ova stored at $10^{\circ} \mathrm{C}$. or at $0^{\circ} \mathrm{C}$. for various lengths of time can develop into normal young when transferred into recipient rabbits. A recent experiment ${ }^{4}$ has further demonstrated that freshly ovulated unfertilized ova can be kept at $10^{\circ} \mathrm{C}$. or at $0^{\circ} \mathrm{C}$. for 48-72 hr. without all losing their fertilizability when transferred into the Fallopian tubes of rabbits which had been bred twelve hours before. This communication reports the subsequent fertilization and the probability of normal development following the transfer of unfertilized ova which had been stored for certain lengths of time.

Unfertilized ova were obtained from the Fallopian tubes of superovulated albino rabbits. The ova were recovered $11-13 \mathrm{hr}$. after the hormone injection which induced ovulation. They were suspended in a mixture of equal parts of buffered Ringer solution and rabbit serum and were stored in small 'Pyrex' tubes, either 